\title{
ЖЕНСКАЯ НАРОДНАЯ ОДЕЖДА СЕТУ
}

\section{Е. В. РИХТЕР}

В 1952 году в советских республиках Прибалтики начала работать комплексная Прибалтийская этнографо-антропологическая экспедиция, организованная Институтом этнографии АН СССР совместно с научными учреждениями академий наук Прибалтийских республик. Задачей этой экспедиции является всестороннее антропологическое и этнографическое изучение народов Прибалтики с целью выяснения происхождения и дальнейшей этнической истории этих народов. Одной из актуальных проблем экспедиции является вопрос культурных взаимоотношений с соседним русским народом, поскольку буржуазные ученые Прибалтики либо игнорировали, либо вообще отрицали какое бы то ни было влияние русского народа на развитие народов Прибалтики.

Для выяснения этнической истории и взаимосвязей народов существенные данные дает исследование материальной культуры и быта. Известно, что наиболее устойчиво сохраняют этническую специфику народа жилище и народная одежда.

Участие эстонских этнографов в комплексной Прибалтийской экспедиции осуществляется двумя отрядами - северным и южным. Работа южного отряда уже в течение двух лет проходила в Вастселинаском районе Эстонской ССР и в Печорском районе Псковской области среди сету и имела своей задачей исследование материальной культуры этой чрезвычайно интересной этнической группы.

В данной статье автор делает попытку на материалах народной одежды проследить этническую принадлежность сету, а также результаты длительного культурного влияния на них соседнего русского народа.

Сету - самая юго-восточная группа эстонцев, живущая в Печорском районе Псковской области и в пределах юго-восточной части Эстонской ССР - в Вастселинаском и Ряпинаском районах. В Печорском районе сету населяют территорию нескольких сельсоветов этого района и живут не сплошным массивом, а селения их разбросаны среди русских деревень. По данным Я. Хурта, сету в конце XIX века насчитывалось 16,5 тысяч человек '. Сету - эстонское народное название этой группы; окружающее их русское население и русские авторы называли их «полуверцами» ${ }^{2}$. Последнее название происходит, вероятно, оттого, что сету

I Я. Х урт, О псковских эстонцах или так-называемых сетукезах. «Известия Русского географического общества», XLI, 1905, стр. 1-22.

2 M. М и ротв орцев, Об эстах или полуверцах Псковской губернии, Памятная книжка Псковской губернни на 1860 г.; Об эстах в Псковской губернии, кПрибалтийский листок», № 4, 1894; Полуверцы Псково-Печорского края, «Московские ведомости», № 282, 1895; Псковские полуверцы, «Новое Время», № 9035, 1901. 
издавна принадлежали к православной церкви («русской»), а язык их эстонский, относящийся к вырускому наречию южноэстонских диалектов.

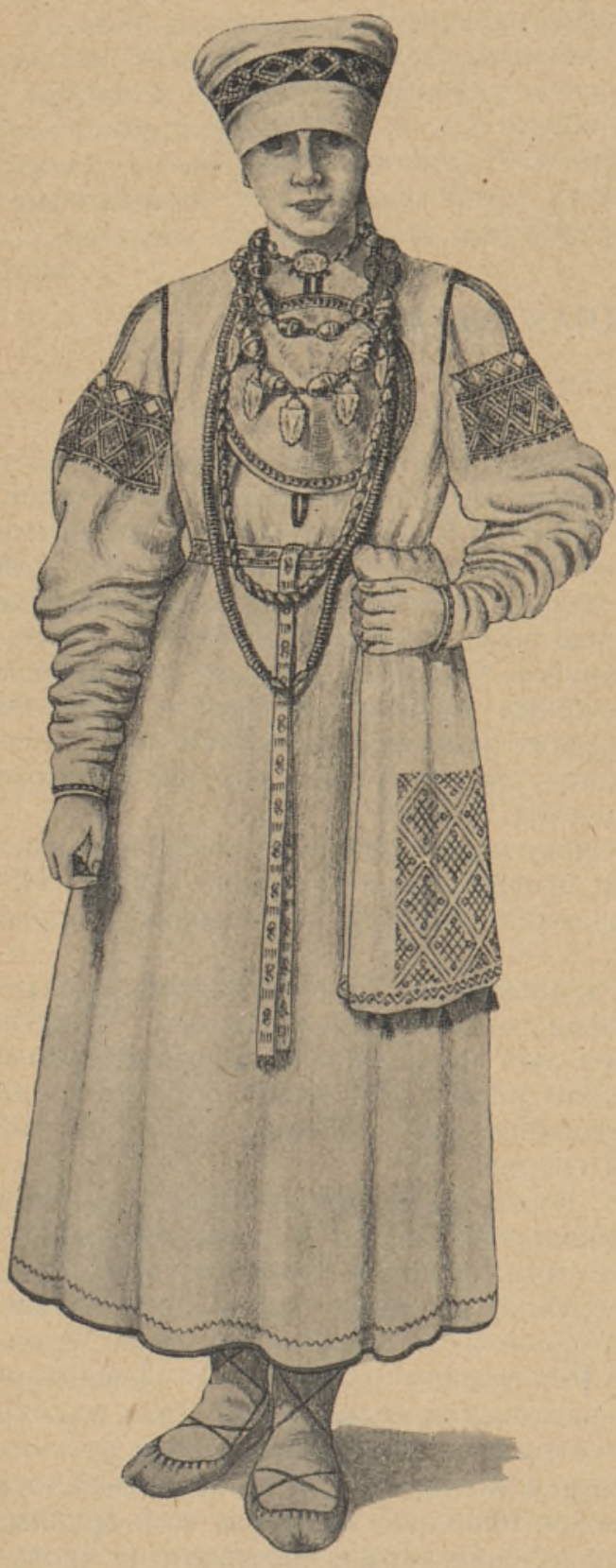

Рис. 1. Ранний тип женского костюма сету.

Сету заселяют пограничные районы этнических территорий русского и эстонского народов и являются как бы переходной группой населения, 'в материальной и духовной культуре которой имеются как эстонские, так и русские элементы. Детально разобрав одну из сторон материальной культуры, именно женскую народную одежду сету (которая довольно устойчиво сохраняет этнический колорит), можно выяснить, какие элементы в ней являются эстонскими и какие русскими.

Сету не раз привлекали к себе внимание исследователей, и имеется целый ряд статей и работ, посвященных описанию их быта, одежды, жилища, обрядов и обычаев. В частности, одежду сету, самобытную и отличающуюся от русской и эстонской народной одежды, детально описывают Я. Хурт, А. О. Хейкель ${ }^{3}$, И. Маннинен ${ }^{4}$. Однако это только описательные работы без глубокого исторического анализа и выводов. В частности, например, Маннинен в своей монографии «История эстонской народной одежды» подходит к материалу чис'’ вещеведчески. Маннинен искусственно разрушает комплекс народного костюма и детально рассматривает его элементы, не соблюдая при этом, однако, принципа историзма. Поэтому на основании работы Маннинена нельзя составить представления ни о комплексах одежды в целом, ни о тенденциях развития одежды, ни о влиянии одежды соседнего, русского народа на развитие одежды сету в разные периоды истории.

По народной одежде сету имеются богатые материалы. Это коллекции

3 A. O. Heickel, Die Volkstrachten in den Ostseeprovinzen und in Setukesien, Helsinki, 1909.

4 J. Ma nninen, Eesti rahvariiete ajalugu, Tartu, 1927. 
фондов Этнографического музея АН ЭССР в Тарту и Государственного музея этнографии народов СССР в Ленинграде. Изучая эти коллекции и используя литературные источники, можно восстановить разновременные комплексы народной одежды сету и проследить, как они изменялись на протяжении целого столетия, начиная с середины XIX века.

Женский костюм сету можно разделить по времени его бытования на два типа: ранний, который носили примерно до середины XIX века, и поздний, дошедший до нашего времени.

Разбор отдельных элементов женского народного костюма следует начать с более раннего его типа, с комплекса, который был распространен до середины XIX века. Он состоял из рубашки, наплечной одежды типа сарафана, верхней одежды и головного убора (рис. 1). Остановимся подробно на каждой из этих частей одежды.

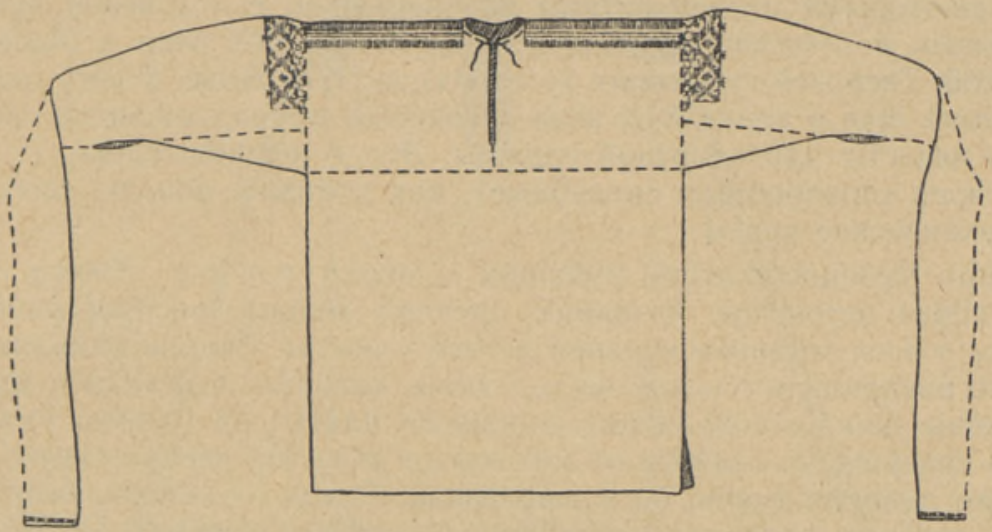

Рис. 2. Схема туникообразной женской рубашки.

Туникообразная рубашка с длинны ми рука вам и имела очень несложный покрой (рис. 2). Все составные части ее были заготовлены на ткацком станке, и дополнительных вырезов или срезов не требовалось. Верх рубашки плечевых швов не имел, к нему пришивались низ и рукава. Рукава тоже имели только один шов - снизу. Они были очень длинными и узкими (длина до 140 см, ширина внизу 10-12 см), и для расширения их в проймы вставлялись клинья. В нижнем шве рукава оставлялось отверстие и в него просовывалась рука, а висящие концы завязывались на спине. Иногда рукава подсучивали, равномерно распределяя сборки от локтя до кисти.

Станина (низ рубашки) состояла из двух прямоугольных кусков, сшитых по бокам. Верх рубашки был украшен вотканными полосами из красной бумажной пряжи, которые шли вдоль плеча. Поскольку в плечах рубашка была значительно шире нормальных плеч, часть наплечных украшений переходила на предплечье, давая начало украшениям рукава. В месте соединения рукава с рубашкой вставлялось неширокое кружево, вязанное на коклюшках из льняных и кумачных ниток. Рукав в верхней части имел свое вотканное украшение из красных бумажных ниток, шириной от 6 до 12 см, состоявшее из полос и геометрического узора. Красные нитки крестьянки получали домашней окраской пряжи корнями моренника, однако уже давно в быт сету вошли также покупные кумач и красные бумажные нитки, которые шли на тканые украшения и плетение кружев.

Следует отметить, что вышивка красными бумажными нитками и 
кумачевые полосы являлись непременным украшением предметов одежды и домашней утвари у русских по всей территории их расселения.

Использование кумача и красной бумажной нитки имело место и в Эстонии, особенно в восточных ее частях.

Туникообразная рубашка является древней формой рубашки вообще. Распространена она была и у эстонцев. В южноэстонском наречии простая туникообразная рубашка называлась hame. Рубашка сету отличается от общеэстонской своими длинными рукавами, поэтому и название ее pitkä käustega hamõ - является описательным, где к древнему слову hamõ было прибавлено определение «с длинными рукавами». У русского населения Псковской губернии рубашки-долгорукавки того же покроя известны уже в XVI-XVII веках и существовали вплоть до середины XIX века ". Туникообразные рубашки с длинными рукавами, правда, отличающиеся некоторыми особенностями по сравнению с псковской рубашкой, сохранились в качестве праздничных до конца XIX века в Московской, Рязанской, Тверской губерниях (у карел), в Приуралье. У сету они также встречались еще в конце XIX века в качестве принадлежности свадебной одежды невесты или смертной одежды. Это и неудивительно - обрядовые одежды (похоронные, свадебные), как правило, дольше всего сохраняют арханческие черты.

Поверх туникообразной рубашки одевали рююд. Рююд - (rüü, иногда rüüd) эстонское название древней, весьма распространенной в прошлом у всех эстонцев верхней летней одежды. Он представляет собой верхнюю распашную одежду из холстины, которую надевали и мужчины, и женщины для предохранения основного платья на работе. Рююд сету (рис. 3) совершенно отличен от эстонского рюю. На изготовление его шла не только льняная ткань, но и шерстяная. Рююд - глухая, безрукавная одежда, которую надевали на рубашку подобно сарафану. Он был очень широк благодаря двум клиньям, которые шли от самой проймы. Спереди имелся грудной разрез, застегивающийся на пуговицы, а вокруг шейного отверстия был пришит стоячий воротник. Замечательны были «ложные» рукава - узкие и длинные (свыше 1 м), которые никогда не употреблялись, были вшиты в плечевые швы и обычно висели на спине под поясом. Рююд имел украшения - грудной разрез, проймы для рук и рукава в кисти были обшиты красным гарусом или тесьмой. Иногда тесьма нашивалась и на подол.

Рююд делились на праздничные и рабочие. Первые шились из шерстяной домотканной материи белого цвета, вторые - из льняной ткани. Постепенно начинает меняться их цвет, что в первую очередь касается рабочих рююд. Так, в описи вещей, купленных у сету в 1894 году, говорится: «Около 1850 года рююд были белого цвета из льна, после этого их стали красить в ржавой воде, позже красили в синий цвет». Белые шерстяные, праздничные рююд сохранились дольше. Еще в начале XX века некоторые старухи ходили в них в церковь, а невесты надевали их на свадьбу.

Подобная наплечная одежда с фальшивыми рукавами не дошла до других районов Эстонии, и для того чтобы понять своеобразие этой одежды, нам следует обратиться к материалам русской одежды, собственно к сарафанам. Наиболее старинной формой сарафана у северных великорусов является косоклинный сарафан с ложными рукавами, вшитыми в плечевые швы, с грудным разрезом. В литературе он называется

5 Д. К. 3 еленин, Описание рукописей Ученого архива Русского географического общества, Петроград, 1916, ХXXII, Псковская губерния, рукопись № 15. 
«псковским» или «шушуном» ${ }^{6}$. Такой сарафан бытовал у русских примерно до XVIII века, сменившись в последующие столетия другими видами сарафанов. Так, у русского населения Псковской губернии глухой сарафан сменился круглым, прямым, со сборками, на лямках.

У сету же покрой старинного псковского сарафана был распространен не только в середине XIX века, но и значительно дольше, сохранившись до середины XX века. В нем только изменились цвет, качество ткани и название. Рююд всегда подпоясывался поясом, который несколько раз обертывался вокруг талии и завязывался спереди. Такие пояса ткали на дощечках или на картах, из цветных ниток, геометрическим узором (основа нитяная, уток шерстяной).

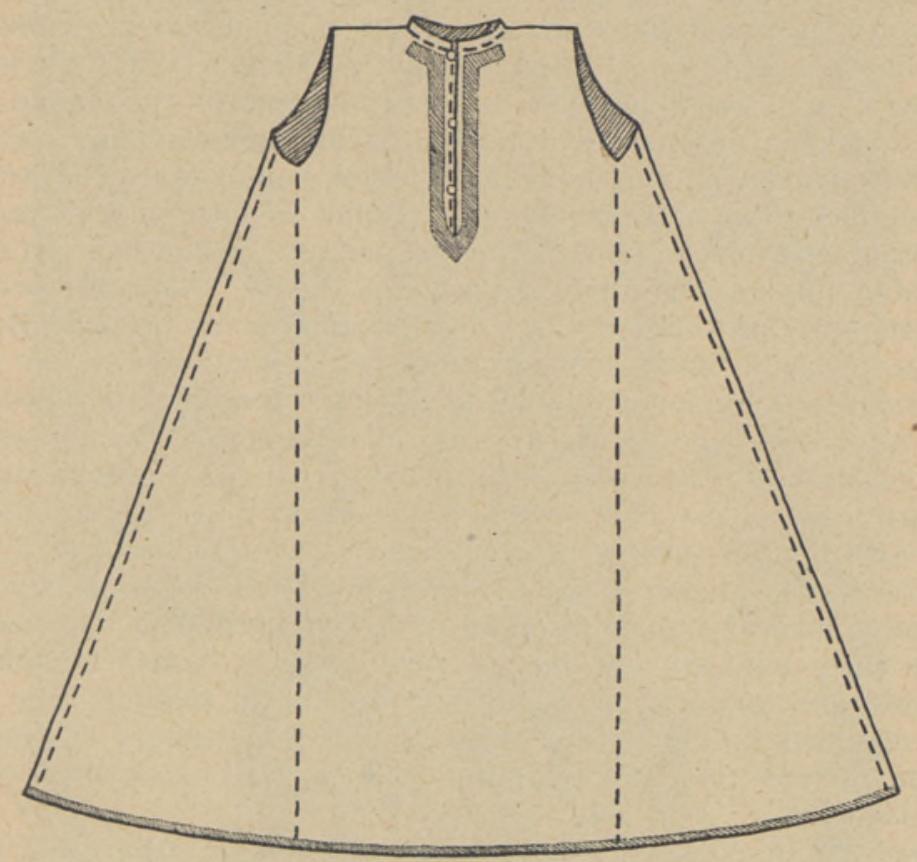

Рнс. 3. Схема женской наплечной одежды рююд.

На поясе сбоку носили н а бед ре н н и к (puusapõll). Своей формой последний напоминает широкое короткое полотенце с расшитыми концами. Способ украшения - вышивка русским двусторонним швом, вышивка настилом или крестом по кумачу. На концах было кружево, плетенное на коклюшках, или бахрома, сделанная из концов ткани. Когда набедренники вышли из употребления, их надевали только невесты. В 1859 году их, очевидно, носили еще все женщины, так как в записи от этого года, где перечисляются предметы женской одежды сету, упоминается не передник (põll), а «набедренник» (puusapõll).

Эта часть одежды является своего рода рудиментом, так как некогда она сочеталась, вероятно, с иным комплексом женской одежды сету, что может быть восстановлено только по аналогии с одеждой женщин южной Эстонии.

Согласно музейным материалам и литературным источникам, в южной Эстонии еще в конще XVIII и начале XIX веков женщины носили поясную

6 Б. А. К у ф ти н, Материальная культура русской мещеры, М., 1926, стр. 114. 
одежду типа поневы ${ }^{7}$ (sōba, pallapoolik). Здесь, однако, имелись свои особенности - шерстяной тканью обертывались так, что края ее сходились не спереди, как у поневы, а на боку. Несходящиеся края прикрывались узким куском полотна (puusapõll или küljerätik). Очевидно, сету, до перехода к «псковсৃкому» сарафану, носили туникообразную рубашку с поясной одеждой типа поневы и набедренником, который в качестве украшения обрядовой одежды невесты сохранился до конца XIX века. Несмотря на то, что и понева, и подобный набедренник имели широкое распространение и у славянских народов (южные великорусы, белорусы, украинцы, поляки), все же у сету этот комплекс является южноэстонским, так как у ближайших восточных соседей сету, русского населения Псковской губернии, он давно сменился глухим сарафаном.

В качестве верхней одежды женщины носили летом рябик (räbik), зимой - белый кафтан (villasärk) и шубу (kasukas). Р я б и к - слово не эстонского происхождения (по данным лингвистики), однако в русских толковых словарях его также нет. Это распашная верхняя одежда типа кафтана, которую женщины надевали летом в прохладную погоду. Шили его из полушерстяной домотканной материи белого цвета, реже из полотна. Покрой его - в талию, спинка цельная. С боков в спине вставлены клинья, собранные в две группы складок таким образом, что каждая группа содержит пять-шесть складок, расходящихся веером. Выше каждой группы складок, вдоль швов спины идут украшения из гарусного шнура зеленого и красного цветов. Украшения из гарусных шнуров нашиты и на край правой полы, но только до пояса, а дальше край обшит покупной тесьмой. Рукава обшлагов не имеют и тоже обшиты шерстяной тесьмой красного, зеленого или черного цветов. Воротника у рябика нет, если не считать пришитой узкой полоски шириной 1 см, которая образует подобие стоячего воротника, ничем не украшенного. Спереди рябик глубоко запахивается справа налево и застегивается на крючок.

Другие виды верхней одежды сету - шуба и белый шерстяной распашной кафтан покроем свонм очень близки к рябику, т. е. сшиты в талию, со сборами на спине. По праздникам или в дорогу женщины надевали зимой поверх шуб белые длинные кафтаны из толстой шерстяной ткани (villasärk).

Для выяснения вопроса происхождения рябика обратимся к верхней одежде соседних с сету народов.

Среди русского населения Псковской и других губерний была широко распространена верхняя одежда подобного типа, различные армяки, зипуны, суконные кафтаны. В рукописях архива Всесоюзного географического общества от 1848 - 1849 годов имеются сведения о верхней женской одежде крестьянского населения указанных губерний ${ }^{8}$. Корреспондент Пароменский пишет, что в Псковской губернии женщины поверх шубы зимой носили белые суконные сермяши. Другой корреспондент, Тихомиров, сообщает о белых холщевых халатах, или балахонах, у женщин. К сожалению, эти сообщения не содержат данных о их покрое. Верхняя одежда из полушерстяной ткани белого цвета была широко распространена и среди русского населения центральных губеений.

На территории Әстонии подобная распашная одежда (pikk-kuub) также представлена большим количеством вариантов как в отношении по-

7 Понева - исключительно женская одежда, состоящая из нескольких полотнищ. соединенных между собой н укрепленных у пояса, и закрывающая по преимуществу заднюю часть тела. Н. П. Г р и н ко в а, Русская понева юго-западных районов РСФСР, «Сборник Музея антропологии и этнографии», XII, M., 1949, стр. 5.

8 Д. К. З ел ени н, Описание рукописей Ученого архива Русского географнческого общества, Петроград, 1916, XXXII. 
кроя, так и цвета. В XIX веке в северной части Эстонии, как правило, кафтаны из шерстяной ткани (pikk-kuub) были синего цвета, который постепенно распространялся и на юг. Однако имеются данные, что в Эстонии древняя одежда типа кафтана на юге была белого цвета и позже сохранилась там в качестве праздничной. В Псковской губернии, в Белорус

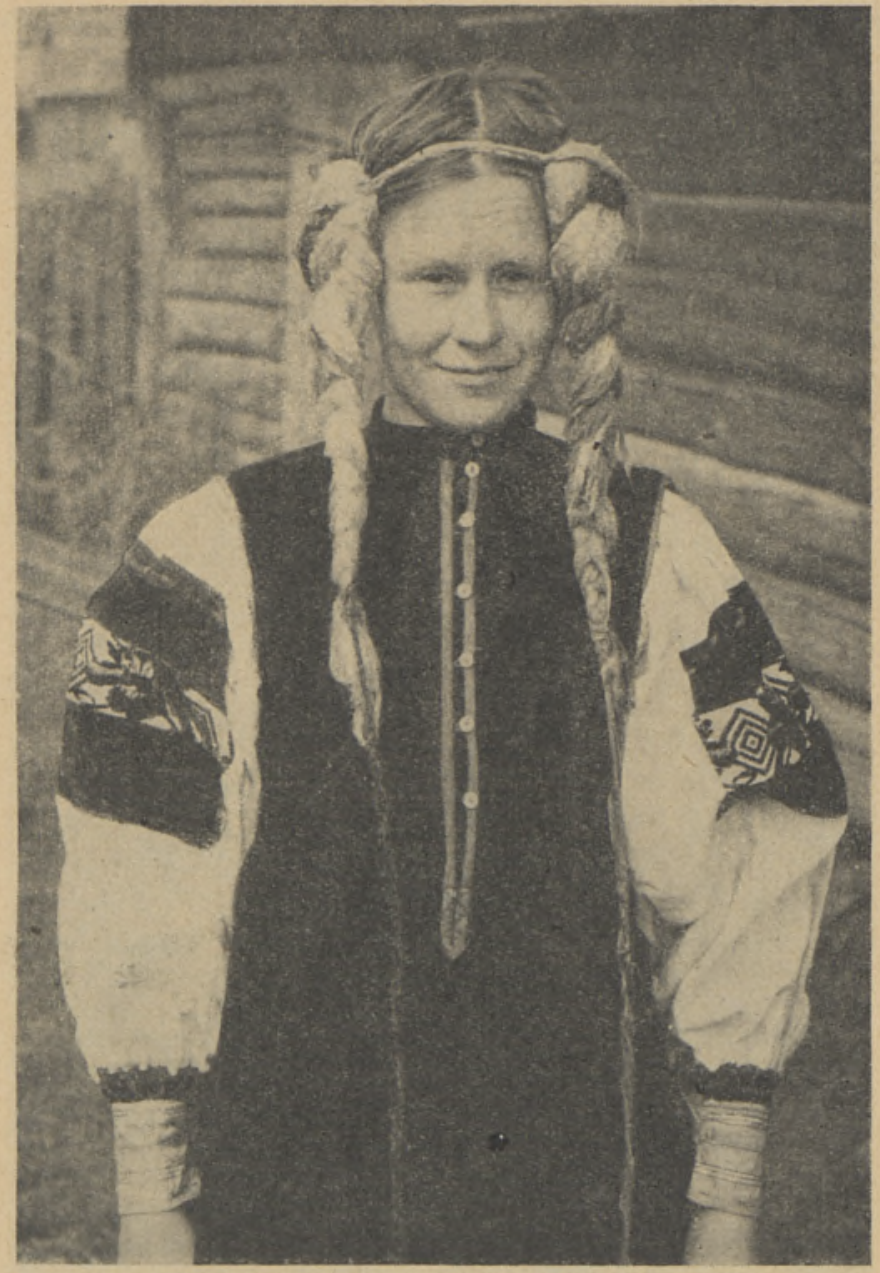

Рис. 4. «Льняные косы» женщины сету.

сии и средней полосе центральных губерний России доминирующим в верхней одежде также являлся белый цвет. Сету восприняли, вероятно, русскую разновидность этих кафтанов, а возможно, что и само слово рябик является производным от русского слова, так как русское население Псковщины называет ткань, в которой основа льняная, а уток шерстяной, - рябой. По аналогии с русеким названием подобной одежды в Тверской губернии - «пониток» 9 , которая названа по качеству материи, можно предположить, что слово рябик произошло так же. Однако для окончательного разрешения вопроса о происхождении рябика надо де-

9 Пониток - домотканная материя, где основа льняная, а уток шерстяной. 
тально изучить древние формы эстонских и русских кафтанов, что даст нам более ясную картину.

Довольно своеобразными являются женские головные уборы сету. Так же как у многих народов, их можно разделить на девичьи и женские.

Девушки сету носили волосы заплетенными в одну косу, однако некогда они носили волосы распущенными, следы чего остались в обычае

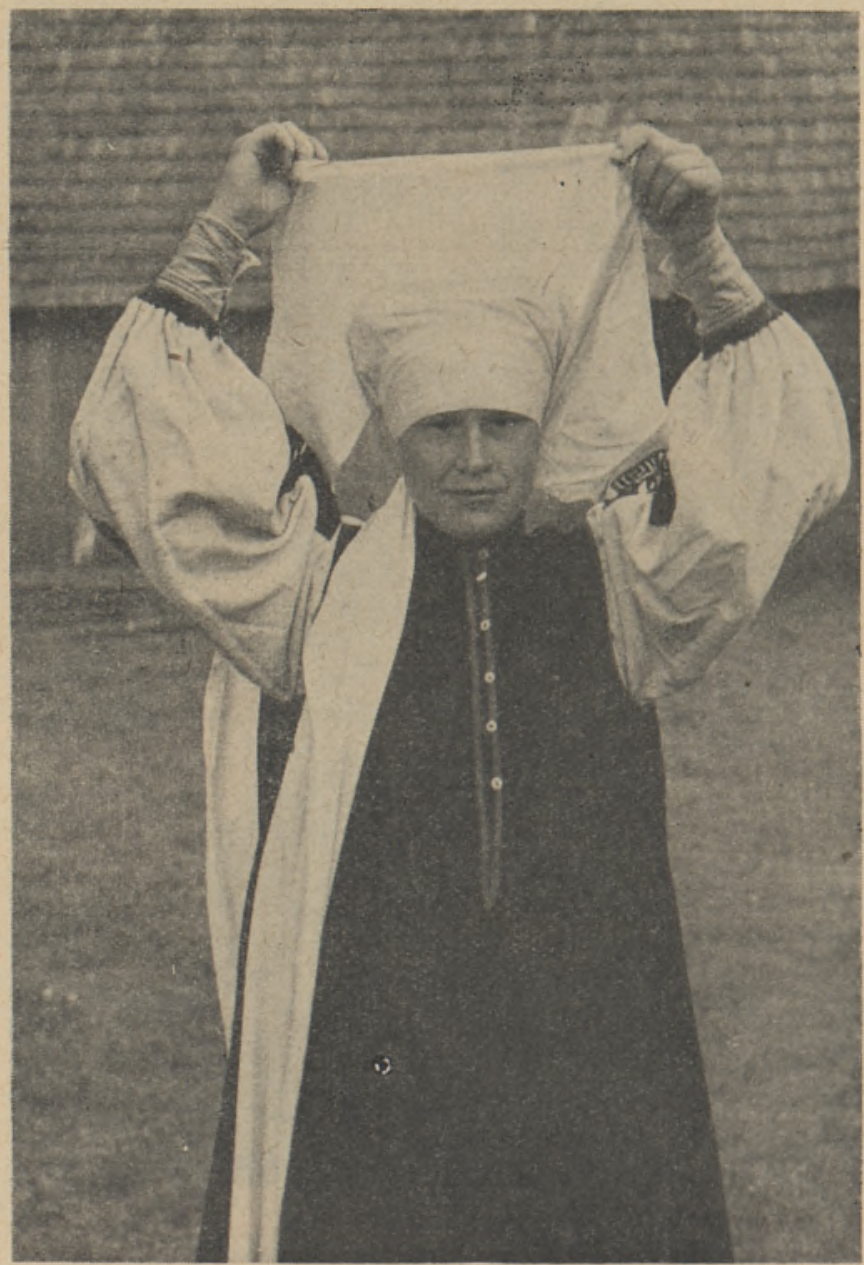

Рис, 5. .Момент повязывания линика.

невесты ходить с такой прической до свадьбы. Незаплетенные волосы у девушек были обычным явлением среди эстонцев и среди всех славянских народов в далеком прошлом. Обычным девичьим головным убором был платок, часто девушки ходили вообще с непокрытой головой. В праздники же надевали специальный головной убор - в а н и к (vanik). Он не покрывал головы и образовался, вероятно, так же, как и у славянских народов, из повязки, поддерживающей распущенные волосы. Ваник - повязка на твердом каркасе, обшитая парчой или шелком; сзади, на месте завязок, прикрепляли «хвост» - кусок шелковой ткани длиной более полметра. Этот «хвост» и концы лент, которые в два ряда повязывались поверх ва- 
ника, спускались на спину. Ваник начинали носить в $16-17$-летнем возрасте, когда девушки впервые выходили на гулянье. И прическа, и головной убор изменялись при замужестве. В день свадьбы молодой в доме жениха делали другую прическу - расплетали косу, делили волосы на две пряди и вплетали в них лен. Получались толстые косы, имеющие начало

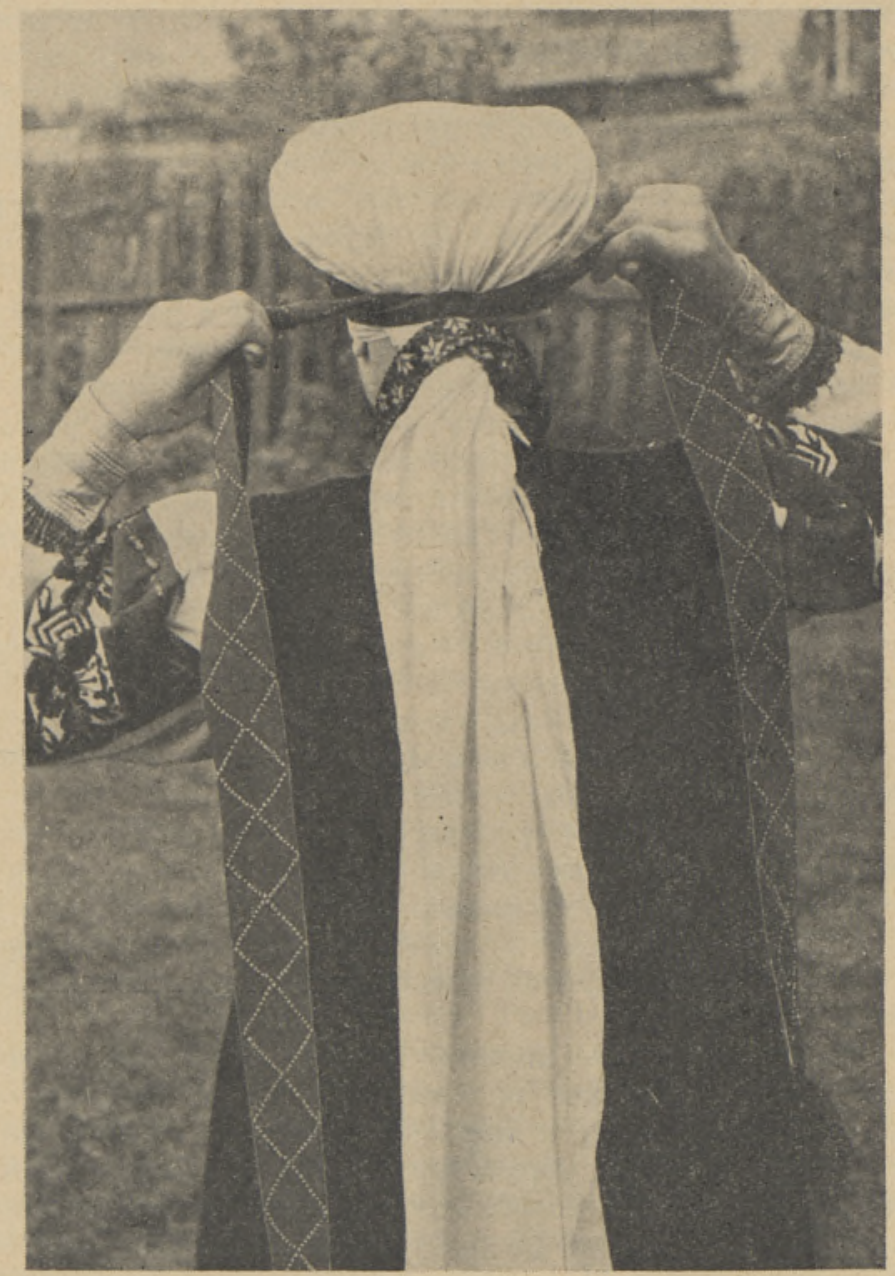

Рис. 6. Головная повязка для закрепления линика.

почти на висках (рис. 4). Когда эти косы обертывали вокруг головы, то получалась прическа, значительно расширяющая размеры головы благодаря особым височным буграм или «рогам». Женщина всегда носила эти косы, не расплетала их даже ночью, и недаром молодая жалуется в свадебной песне: «Не дают больше дня видеть, не дают волосы проветрить, солнцу смотреть, на голове косы заплетают как веревку» ${ }^{10}$. Эти льняные косы и обусловленная ими форма головы резко отличали женщину сету от русских женщин Псковской губернии, - последние носили волосы под гладким повойником. Обычай добавления льна в волосы у сету является

10 Этнографический архив Этнографического музея (ЭМ) АН ЭССР, т. 28, стр. 661. 
эстонским, так как известно, что на территории южной Эстонии в прошлом у замужних женщин был широко распространен обычай вплетать в волосы лен.

Женский головной платок л и н и (linik) относится к типу головных полотенец, покрывающих волосы женщины. Линик изготовлялся из самого лучшего домашнего полотна (позже сотканного из фабричной пряжи); ширина его составляет 30 см, длина от трех до четырех метров, в зависимости от роста женщины. Для того чтобы покрыть всю голову узким лиником, приходилось его обертывать дважды: первый раз лиником обертывали лоб и темяную часть, вторым обертыванием охватывали прическу из льняных кос и покрывали также затылок (рис. 5). Поверх линика надевали головную повязку (реа-vӧӧ), которая плотно держала линик и подчеркивала форму кос (рис. 6). Длинный узкий линик имел украшения только на концах; по технике выполнения и по цвету они были аналогичны украшениям рубашек. Все украшение в целом имело ширину $8-9$ см. Иногда к вотканным полосам пришивались неширокие куски кумача, на которых вышивался геометрический узор синими, белыми и желтыми нитками. Қ краю линика также пришивались кружева, плетенные на коклюшках из белой льняной и красной бумажной ниток. Украшение не оставалось постоянным, оно развивалось - увеличивалась ширина кумачной вставки, усложнялась геометрическая вышивка. Украшения линика, таким образом, полностью гармонировали с украшениями рубашки и развивались параллельно им. Весь женский костюм этого времени имеет сочетание двух цветов - основного белого и красного, которым украшались отдельные его части. Белая рубашка, рююд, линик, набедренник, рябик - все они были украшены красной пряжей или кумачом. Головная повязка, надеваемая поверх линика, также красного цвета и выполнена из алых шерстяных ниток.

Линик играл большую роль в свадебной обрядности. Обряд надевания линика (linotamine) знаменовал собой превращение невесты в молодую. После этого замужняя женщина носила линик постоянно, даже на работу. B середине XIX века подобный головной убор был уже этнической особенностью сету, так как у других эстонцев и у соседних русских он уже не встречался.

Каково же происхождение линика? Подобные полотенчатые головные уборы имели некогда широкое распространение среди славянских, прибалтийских, восточнофинских и тюркских народов. Старинные головные уборы - у русских женщин убрус, ширинка, украинская намитка, польская завойи, литовский нуометас, латышский наметс, марийский шарпан, башкирский полотенчатый убор и чувашское головное полотенце, сурпан - вот краткий перечень головных уборов типа полотенща. Линики были известны также на всей территории Әстонии; дольше всего они сохранились в восточной Эстонии. Линики из бывших Тартумаского и Вырумаского уездов были длиной до трех метров; конщы некоторых из них украшались красными вотканными полосами, реже какой-нибудь вышивкой. Позднее в Эстонии линик потерял значение головного убора, но долго еще сохранялся как свадебный подарок в виде нарядного полотенца. В Пыльваском районе еще в конце XIX века линики ткали по старому обычаю, изготовляя их для свадебных подарков матери и сестрам жениха. И все же к концу XIX века линики в Эстонии повсюду исчезли из употребления, были заменены чепцами, и о бытовавшем некогда головном уборе напоминает только название обряда надевания на молодую чепца «линутамине» (linutamine), что, конечно, восходит к тому времени, когда непременным атрибутом замужней женщины был линик (сравни название этого обряда у сету - linotamine). 
У русских женщин Псковщины нет головных уборов типа линика. «У великорусов наметка давно заменена простым платком. Сохранились старые наметки кое-где в Орловской, в Нижегородской и соседних губерниях под названием: повязка, ширинка, полотенце, длиною они до 150 см и более; делаются из белого домотканного холста, концы которого иногда перетканы красными полосками» "1. На Псковщине старинным головным убором замужних женщин была «сорока», которая, вероятно, возникла из ширинки» ${ }^{12}$. Позже длинные полотенца стали играть роль только свадебных подарков и декоративных украшений в избе. Украшения на этих полотенцах были выполнены той же техникой и в той же расцветке, что и линик сету, но в качестве головных уборов они уже давно не употреблялись. Поэтому не представляет никаких сомнений, что линик, наряду с добавлением льна в прическу, входит в группу южноэстонских головных уборов, который у сету удержался значительно позднее, чем у остальных эстонщев. Рубашка с длинными рукавами и рююд, по существу, сходны с подобной русской одеждой, головной же убор, который был известным образом связан с обрядностью (свадебной), остался у сету эстонским и бытовал одновременно с народным костюмом.

О бу в ь сету почти не отличается от обуви соседей. Летом женщины (так же как и мужчины) ходили босиком, а на работе носили лапти (viisud) и поршни (tsuuvi), с которыми надевали портянки-онучи (jalanartsud) и обмотки (rasu или ribad). Зимой носили также шерстяные чулки (kapuda), которые вязали без пятки. Женские чулки отличались от мужских: их делали из белой шерсти. Мужские же чулки, которые надевались поверх штанов, имели в верхней своей части яркие узоры, вывязанные разноцветной шерстью.

Для праздничного наряда сету характерно обилие мет ал л и че с к и х ук р а ше н и й, покрывающих всю грудь женщины. Центральное место среди них занимала коническая пряжка - сыльг (sõlg), достигающая у сету особенно больших размеров. Изготовлялись эти пряжки из самого низкопробного серебра. По форме сыльг представляет собой усеченный конус, в верхнем отверстии ее имеется свободно вращающийся поперечный язычок, при помощи которого сыльг прикрепляется к рубашке. Внешняя поверхность пряжки покрыта выгравированным орнаментом растительного или геометрического характера. Сыльг, как и другие нагрудные украшения, начинали носить только в девичьем возрасте, когда девушка получала право носить полный костюм сету. Пряжка сыльг считалась самым ценным украшением женщин и девушек и переходила обычно по наследству. Кроме сыльг, сету носили большое количество шейных украшений, различных бус и цепочек. Очень было распространено ношение серебряных монет. Из бус выделяются крупные полые бусы в форме грецкого ореха с маленькими выпуклинами на поверхности и привески в форме серебряных пуговиц - puugnits. Характер этих украшений станет ясным, если привлечь матернал по нагрудным украшениям соседнего населения. Нагрудные серебряные украшения характерны в прошлом для эстонцев вообее. Так, конусообразная сыльг эстонская форма пряжки - была распространена в южной Эстонии. Крупные бусы (kôrrahelmed) также представляют собой эстонское украшение,

11 Д. К. Зеленин, Женские головные уборы восточных славян, Журнал «Slavia», вып. II, 1926, стр. 320.

12 Слово жширинка», обычное в русском фольклоре, буквально означает широкое полотенце. Даль дает следующее объяснение ему: «Убрус, плат, платок, фата, ширинка, полотенце, особенно нарядное и браное... Убрус новоженный, почетная ширинка, подносимая молодою на поклон», (Даль, Толковый словарь жнвого великорусского языка, т. IV, 1884, стр. 471). 
которое у сету удержалось дольше, чем у других эстонцев, носивших их в XVI-XVII веках. То же можно сказать и о серебряных монетах. Однако в украшениях сету имеются и свои особенности. Крупные витые цепочки не встречаются у эстонщев и заимствованы сету у окружающего их русского населения. Русские женщины Печорского района имели только одно нагрудное украшение - обвитую вокруг шеи крупную цепочку и привеску на последнем круге («замок»). Именно этой формы цепочка и перешла к сету. Русскими являются названия привески - puugnits и цепи, на которую вешали крест - tsaputska (псковское - цяпоцка).

Комплекс женского костюма, описанный выше, существовал у сету примерно до 60-х годов XIX века. Изменения, которые произошли к этому времени в деревне в связи с развитием капиталистических отношений и товарного хозяйства, привели к частичному исчезновению крестьянской домашней промышленности. Льноводство, которое издавна играло большую роль в Псковской губернии, приобретает теперь товарно-промысловое значение. Малоземелье и низкое качество земли толкали крестьян на поиски дополнительных доходов. С ростом товарно-денежного хозяйства в деревню проникают все в большем количестве фабричные товары. Вместе с тем, все же «деревня еще сохраняла много пережитков полукрепостнических отношений и натурального хозяйства. Процесс отделения промышленности от земледелия еще не был полностью закончен, почему и покупательная способность деревни на продукты капиталистической промышленности хотя и быстро возрастала, но была невысока» ${ }^{13}$.

Появление мелких заведений красильщиков («синильников»), распространение фабричных тканей и анилиновых красок приводило в некоторых случаях к изменениям в народном костюме, а позже и к его исчезновению. Однако, в силу ряда обстоятельств, процесс этот происходил поразному у сету и у русских. Русские к концу XIX века переходят уже частично на городскую одежду, у сету же сохранились не только отдельные элементы, но и весь комплекс народного костюма.

В более позднем комплексе женской одежды сету (рис. 7) сохраняются те же основные элементы, что и в раннем, в то же время целый ряд элементов изменяется, что было вызвано как общеэкономическими условиями, так и усилением связей с русским населением.

Р уб а шк а с длинными рукавами постепенно сменяется другим типом рубашки. У русского населения Псковщины в середине XIX века получают распространение холщевые рубашки с пышными рукавами (в праздник - кисейными), которые Б. А. Куфтин называет поздним или новгородским типом северовеликорусской рубашки ${ }^{14}$.

Сету заимствуют у русского населения рубашку с пышными рукавами, но сохраняют в ней все же известную специфику в украшениях. Известно, что русские женские рубашки новгородского типа не имели украшений на рукавах. Сету переносят на новый тип рубашки свои традиционные украшения, технику и орнамент и развивают их дальше. Называют сету этот тип северовеликорусской рубашки прежним словом южноэстонского наречия - hamõ.

На рис. 8 видно, чем именно отличается новый тип рубашки от туникообразной. Рукава здесь очень пышные и идут непосредственно от ворота. Они состоят из двух кусков самого лучшего, нередко фигурного полотна, с вотканным украшением на верхнем куске. Ворот рубашки собран, и

13 П. И. Лященко, История народного хозяйства СССР, издание $3-е$, M.. 1952, стр. 115.

14 Б. А. К у фтин, Материальная культура русской мещеры, Часть I, Классификация рубах, М., 1926, стр. 19-46. 
вокруг него пришит узкий стоячий воротник. Рукава рубашки являются одним из главных элементов, украшающих весь женский костюм, и в этом отношении они намного превосходят рубашки раннего типа. На музейных материалах прекрасно прослеживается развитие этих украшений. Наиболее ранние экземпляры имеют очень скромно украшенные рукава. Иногда это неширокие вотканные пөлосы из красных бумажных ниток ${ }^{15}$, иногда - узкий геометрический узор, повторяюший узор тканых поясков. Встречаются и такие рукава, на которых нашита поперечная полоска кумача, вышитая крестом белыми и синими нитками ${ }^{16}$.

Со временем тонкая красная нить для ткани орнамента заменяется толстой бумажной нитью и ею набирается при тканье более рельефный и широкий узор. Постепенно вырабатывается и определенная форма расположения узора. Узкий геометрический узор ограничивается двумя вотканными полосами, которые с течением времени становятся более широкими. В конце XIX века бумажная пряжа заменяется шерстяной, фабричного производства (так называемыми «рижскими нитками» - riialanga). Ширина всего украшения рукава достигает 20 см. У кисти рукав собран и оканчивается обшлагом из кумача или красного сатина. Украшали сету и праздничные, и повседневные рубашки, а рубашку без узоров надевали только в траур, что наряду с черным платком и отсутствием передника было обязательной формой одежды в течение шести недель. Таким образом, новый тип рубашки сету является рус-

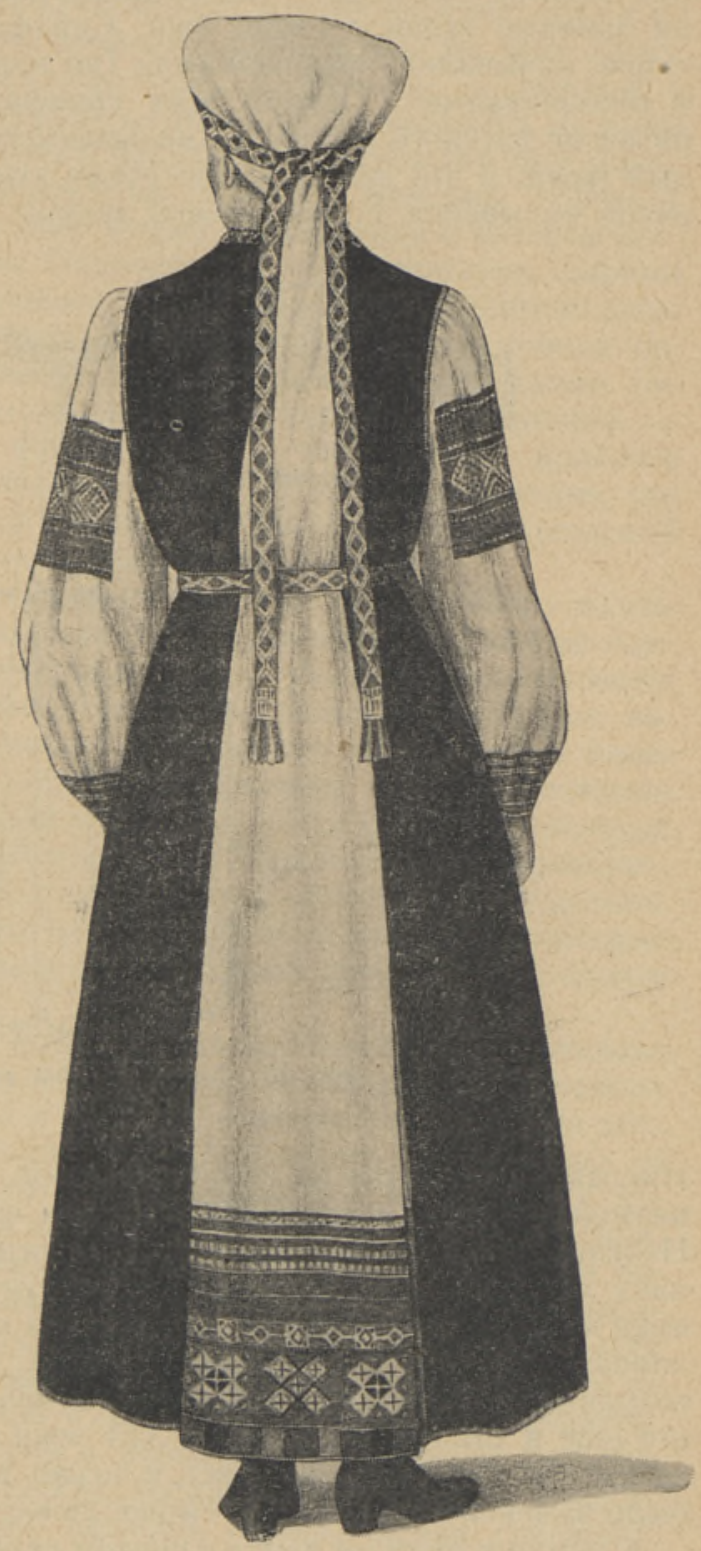

Рис. 7. Поздний тип женского костюма сету. ским; подобное расположение вотканных украшений рукавов широко распространено также среди белорусов и украинцев, однако геометрический орнамент у сету является староэстонским и сменяется растительным орнаментом лишь в $30-\mathrm{x}$ годах текущего столетия. 
В 60-х годах XIX века происходят изменения и в наплечной одежде р ю юд, которые коснулись прежде всего не покроя, а цвета. Во второй половине XIX века в русской деревне получают большое распространение изделия кустарей - набойщиков (синильников), которые окрашивали льняные ткани в синий цвет. Сарафаны, изготовленные из подобной ткани, назывались «кубовиками» (по народному названию синей краски) и «набойниками». Покрой этих сарафанов представлял собой позднее развитие русского сарафана, называемого круглым или московником. Белый рююд в это время также стали красить в синий цвет; окрашенный рююд назывался у сету «новой модой». Покрой его оставался прежним.

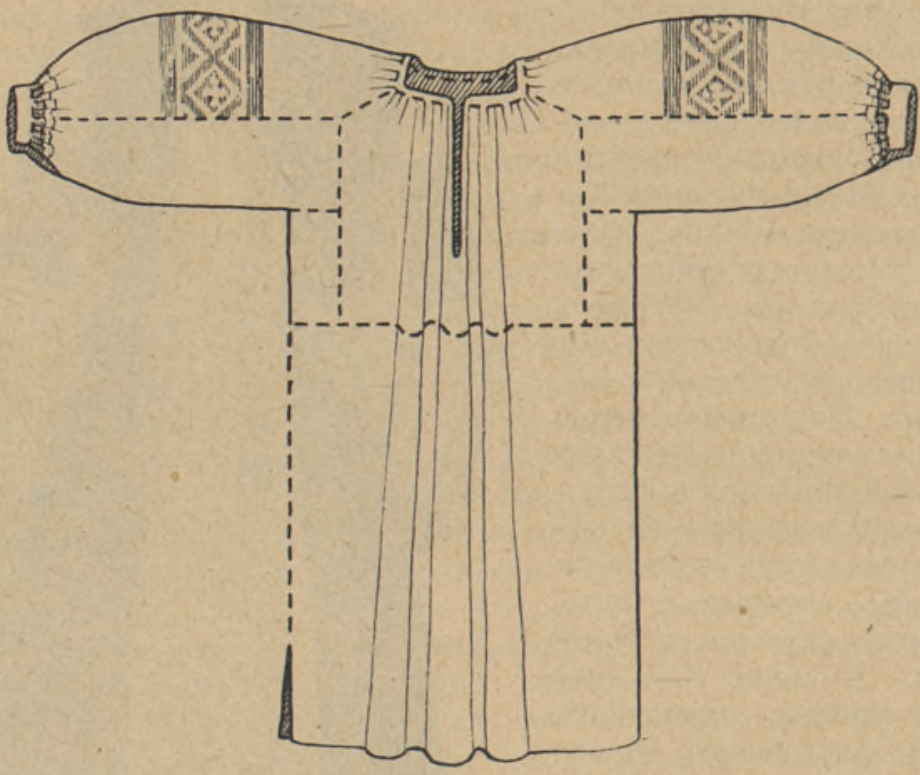

Рис, 8. Схема поздней женской рубашки.

Иногда рююд шили из синей покупной хлопчатобумажной ткани, называемой в народе «китайкой». Русским известны сарафаны «китаечники». Название, которое сету дали рююд, сшитому $>3$ покупной ткани - «китасник» является, видимо; искажением русского слова «китаечник». Қитасники являлись «выходной» одеждой, а в качестве рабочей оставался белый холщевый рююд. Шерстяной рююд - праздничная одежда - дольше сохранял неизменным белый цвет, и некоторые старые женщины носили его еще в 1920 году. В конце XIX века также и шерстяные рююд стали красить в синий и черный цвет, а позже, в начале XX века домашнее сукно было заменено піокупным. Темный рююд стал назы́ваться «сукманом».

Сукман в русском языке означает сарафан из сукманины (полушерстяная домотканина) и широко известен не только в центральной и северной частях России, но и у зарубежных славянских народов (например, у болгар). И у русских, и у болгар сукманы относятся к глухим косоклинным сарафанам с ложными рукавами. Сукман сету своим покроем очень близок к северному варианту сукмана, северновеликорусскому шушпану или псковскому сарафану. Ложные рукава, которые являются непременной частью и северного, и южного вариантов, украшали сукман сету в некоторых случаях вплоть до первой мировой войны. Маннинен считает длинные рукава сукмана последним отголоском средневековой моды в Евро- 
пе ${ }^{17}$. Это заключение Маннинена, несомненно, совершенно ошибочно. Сету восприняли старинный псковский сарафан у русских и сохранили его до XX века. Доказывает это как русское название, так и единство покроя.

С появлением китасника и сукмана входит в употребление п е р д н и к, который заменил собой «набедренник», надеваемый на пояс сбоку.

Головные уборы изменились мало, а прически - девичьи и женские - остались теми же. У девушек ваники стали выходить из моды только в конце XIX века и заменились покупными шелковыми или парчовыми платками. Большей устойчивостью обладал женский головной убор - линик, который сохранил свою форму и изменения в котором коснулись только украшенных концов. Одновременно с увеличением ширины вотканных украшений рукавов нового типа рубашки, становятся шире также и концы линика. Цвет, техника, орнамент украшений концов линика попрежнему полностью соответствуют вотканным украшениям рукавов рубашки. Повязка, которую женщины надевали поверх линика, pea-vöö (буквальный перевод - головной пояс) также была красного цвета. Известно, что в XIX веке их покупали в Печорах на ярмарке, так как подобные пояса представляли собой продукцию русской кустарной промышленности, широко расходившуюся по всей России.

Русские женщины Печорского уезда в качестве праздничного головного убора носили треугольные «косынки», которые обычно были из парчовой ткани или шелка. Сету не оставили своих традиционных головных уборов, но «обновили» их парчовыми платками (kuldrätt), которые носили по-разному. В праздники девушки сворачивали их трубкой и повязывали поверх ваника, женщины надевали их поверх линика и повязки pea-vöö, завязывая узлом на затылке или под подбородком, как обычный треугольный платок. В качестве добавления к свадебному костюму парчовые платки сохранились до 20 -х годов XX века у невесты и у подружек.

На печорской ярмарке женщины покупали себе полусапожки, которые в течение длительного времени были традиционной праздничной обувью женщин и девушек.

Мужская народная одежда сменилась городской одеждой значительно раньше, чем женская, уже в конце XIX века. В. И. Ленин, характеризуя последствия развития капитализма в деревне, отмечает как одно из них, что с этого времени «прежняя оторванность одичалого земледельца от всего остального мира была сломана окончательно» ${ }^{18}$. У мужчин сету, которые были вынуждены уходить на заработки в город и другие губернии, служить в царской армии, сопровождать обозы со льном из Пскова и которые, как правило, владели русским языком, процесс перехода к горөдской одежде совершался одинаково с русскими. Но и до этого, когда у сету еще существовал мужской народный костюм, он уже мало отличался от мужской одежды русского населения и состоял из рубашки-косоворотки, выпускаемой поверх штанов, кафтана и поршней с онучами. В качестве праздничной одежды сету, как и русские, носили белые кафтаны и яркие шерстяные чулки до колен. Верхней одеждой служил армяк (härmak). Отличие по сравнению с русской мужской одеждой заключалось в покрое штанов и украшении праздничных рубашек тканым геометрическим орнаментом. Терминология мужской одежды, однако (за исключением армяка), сохранилась эстонская.

B конце XIX века у мужчин получили распространение «пинжаки» отчасти из покупного сукна, жилеты, суконные брюки. Исчезли яркие носки, по праздникам носили русские сапоги. Рубашки стали шить из

17 I. $M$ a n n in en, Eesti rahvariiete ajalugu, стр. 165, 166.

18 В. И. Л ен ин, Соч., т. 3, стр. 269. 
ситца и сатина. Следовательно, мужская одежда сету потеряла свою специфику уже давно, до перехода к городской одежде. Женская народная одежда оказалась гораздо более устойчивой и сохранилась отчасти до наших дней (рис. 9).

Костюм сету очень своеобразен и красив. Черный сукман, сильно расклешенный внизу, туго перехвачен цветным поясом и придает всей фигуре

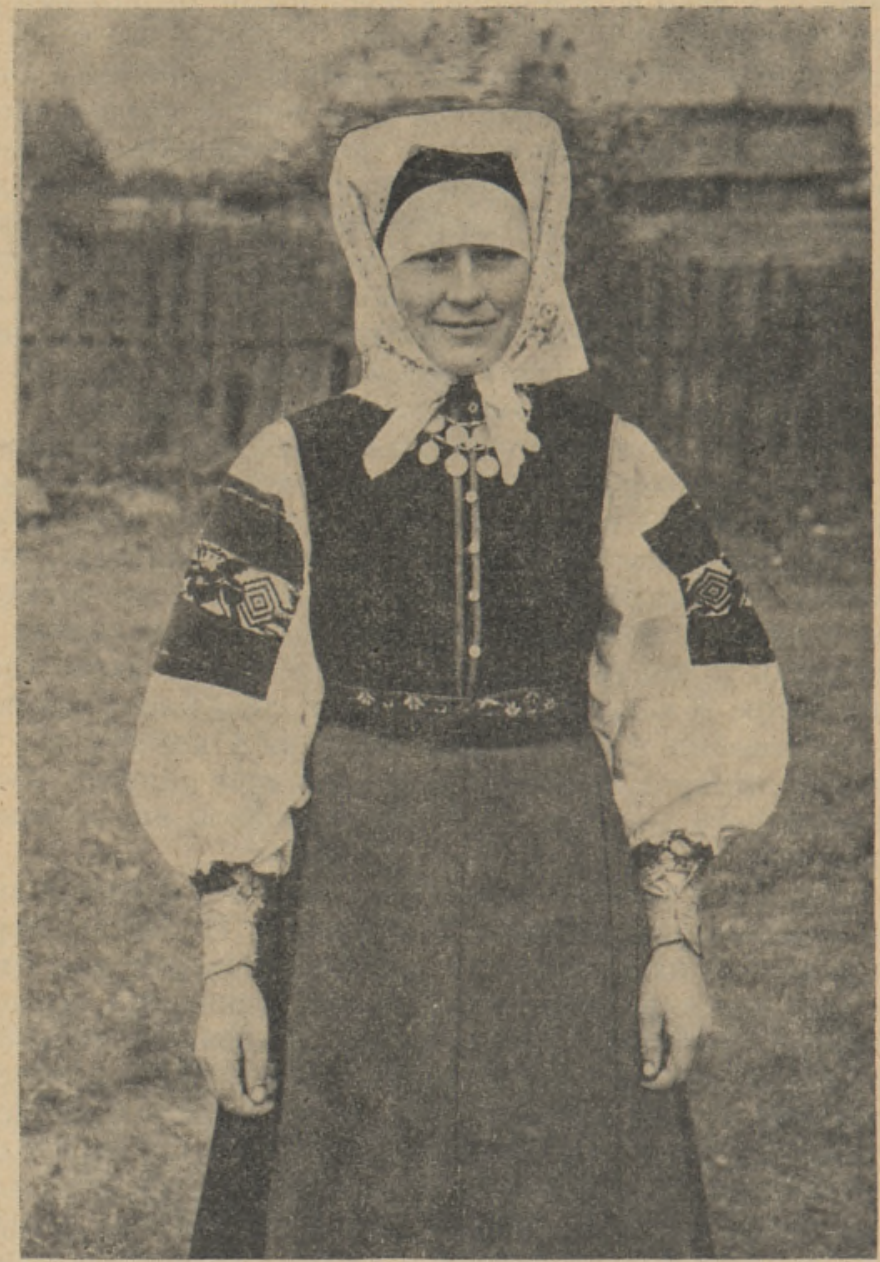

Рис. 9. Женский костюм сету в настоящее время (фото 1952 года).

женщины стройность. На его фоне контрастно выделяются белые широкие рукава рубашки с широкой поперечной полосой темновишневого цвета (которая занимает почти половину рукава) и висящий вдоль спины белоснежный линик с широкими затканными украшениями на концах, с головной повязкой темновишневого цвета поверх его. Грудь покрыта многочисленными металлическими украшениями. Этот костюм ценился и соседним русским населением Печорского района; русские девушки в 20-х и 30-х годах XX века, т. е. значительно позже исчезновения русского народного костюма, надевали его на гулянья. 
Костюм этот является в настоящее время, конечно, анахронизмом, находится в стадии исчезновения и дальше не развивается. От него давно отказались девушки и большинство женщин, перейдя на городскую одеж ду. Перемена в одежде происходит в связи с общей реконструкцией всего быта сету. Объединенные в колхозы. охваченные обучением на родном (эстонском) языке, сету интенсивно преодолевают ту отсталость и консерватизм, которые существовали у них еще в недалеком прошлом. Создаются кадры местной колхозной интеллигенции. Эта интеллигенция и молодежь, которая учится в городе или отбывает военную службу в частях Советской Армии, являются проводниками городской культуры. Быстро исчезают вековые пережитки и те черты отсталости, которые были вызваны крайне низким экономическим уровнем и известной этнической изолированностью сету.

Те достижения народного творчества, которые проявлялись в отделке некоторых элементов костюма (вотканные украшения, например), несомненно будут использоваться и в дальнейшем, но в другой форме. В основном же эстетические потребности народа удовлетворяются теперь благо даря широкому проникновению в колхозную деревню продукции текстильной промышленности.

Изложенный материал позволяет в основном наметить те пути, которыми развивался народный костюм сету. Наши выводы, правда, могут считаться лишь предварительными. Для того чтобы разрешить все возникающие при изучении одежды сету вопросы, надо значительно шире привлечь сравнительный материал по соседнему, главным образом русскому населению сопредельных районов, который мы, к сожалению, пока знаем еще слабо.

Материалы, имеющиеся в нашем распоряжении, позволяют проследить развитие народного костюма сету лишь с первой половины XIX века. О более древнем комплексе можно судить только по отдельным элементам. Анализ этих элементов приводит нас к заключению, что древний комплекс одежды сету был в основном общим с древним южноэстонским комплексом. В женскую одежду входили, повидимому, туникообразная рубашка, поясная одежда типа поневы (pallapoolik, sõba), набедренник (puusapõll, küljerätik), большой наплечный платок (kaal), головное полотенце (linik), нагрудные украшения (sõlg, kõrrahelmed). Но при этом одежда сету имела черты, общие с-женской одеждой славян (обувь, белый цвет одежды). Недостаток материалов по древней русской одежде Псковщины не дает возможности сделать необходимые детальные сравнения с одеждой этого времени.

- Несмотря на всю замкнутость и ограниченность, характерные для эпохи феодализма, сету, составляющие иноязычную группу в среде русского населения; испытывали сильное культурное влияние русского народа. Как результат этого длительного влияния возникает женский костюм, доживший до середины XIX в., в котором основные части - туникообразная рубашка с длинными рукавами, украшенными по плечу и рукаву, и наплечная одежда типа сарафана (рююд) восприняты из русской одежды. Но несмотря на наличие наплечной одежды русского типа, ее нельзя отождествлять с северовеликорусским костюмом, так как сетуская одежда сохранила в значительной степени свои древние элементы. Такие части костюма, как головной убор линик и связанная с ним прическа из льна, набедренник и нагрудные украшения, бытовали в южной Эстонии еще в XVIII веке и в начале XIX века. Названия всех предметов одежды также эстонские (точнее - южноэстонские). 
Развитие товарного хозяйства и капиталистических отношений в деревне во второй половине XIX века приводит к ликвидации феодальной замкнутости, к усилению связей между русскими и сету, что отражается и в появлении нового, позднего комплекса женского костюма сету. В нем точно так же, как и в раннем комплексе, изменились прежде всего рубашка и наплечная одежда. Сету, видимо, почти одновременно с русскими оставляют рубашку-долгорукавку и начинают носить рубашку с пышными рукавами (новгородский тип) и поверх нее синий, позже черный «китасник» и «сукман». Те же элементы костюма, которые играли определенную роль в обрядах, были связаны с древними обычаями, продолжали и далее оставаться староэстонскими. Ярче всего это проявляется в головных уборах. Девичий ваник быстро сменяется шелковым или парчовым платком, а линик и связанная с ним прическа с добавлением льна, знаменующие собой замужество, доживают до наших дней. Некоторые нагрудные украшения, которые в прошлом имели определенное магическое значение, сохранились в силу традиции эстонскими, но к ним присоединяются и русские украшения с заимствованными названиями (tsaposka, puugnits). То же мы наблюдаем и в орнаменте. Сету, также как русские, украшали отдельные элементы одежды вотканными узорами, овладели техникой русского двустороннего шва и креста, но орнаментальные мотивы сохранили эстонские. Древний русский орнамент в виде богини земли с зверями и деревьями, широко известный среди населения Новгородской земли и ее колоний, сету не восприняли.

Тесное общение сету и русских приводило, с одной стороны, к постепенному исчезновению древнеэстонских элементов одежды и замене их русскими, с другой стороны, к появлению особых форм одежды, в которых сочетались эстонские и русские черты. Основное направление развития одежды сету шло в сторону усиления русского влияния и уменьшения эстонских элементов, что можно проследить не только в одежде, но во всей материальной культуре сету, а также в обрядах, фольклоре и языке.

Этот вывод имеет несомненный интерес для разрешения вопроса о происхождении сету. На основании того, что культура сету представляет собой как бы переплетение элементов русской и эстонской культур, ставился вопрос, кем же собственно являются сету, проживающие в полосе русско-эстонской этнической границы - эстонцами, находящимися в стадии ассимиляции или обэстонившимися русскими. Из результатов нашего первоначального анализа народной одежды явствует; что сету по своему происхождению - эстонцы, подвергшиеся в течение своей истории значительному русскому влиянию.

Әтот же вывод с еще большей убедительностью подтверждается анализом народной архитектуры и всей материальной культуры сету.
Ннститут истории
Академии наук Эстонской ССР
Поступила в редакцию
$31 \times 1953$ 